\title{
Direito Urbanístico: O Modelo da Cidade-Média como Técnica Urbanística de Integração e de Sustentabilidade entre os Espaços Urbano e Rural na Efetivação da Função Social da Cidade.
}

\author{
Frederico Price Grechi ${ }^{1}$
}

1. Introdução. 2. A constitucionalização do Direito Urbanístico: a dignidade da pessoa humana como vetor axiológico unificador do ordenamento jurídico. 3. O novo papel do Direito Urbanístico e a sua relação com os demais ramos do Direito. 4. Direito Urbanístico: o Estatuto da Cidade (Lei no. 10.257/2001) e as suas diretrizes gerais. 5. A integração e a sustentabilidade entre os espaços urbanos e dos espaços rurais como função social da Cidade. 6. O modelo da cidade-média como técnica urbanística para integração e sustentabilidade entre os espaços urbano e rural. 7. Bibliografia.

Resumo: Direito Urbanístico após o advento da Constituição Federal de 1988 ganhou importância no estudo do Direito esse intensificou com a publicação da Lei n. 10.257/2001Estatuto da Cidade.Tomando como parâmetro os modelos de cidades-média como aquela técnica urbanística a ser adotada por parcela representativa dos Municípios brasileiros em seu plano diretor posto, se cria um novo perfil de território, promovendo a integração entre os espaços urbano e rural e do desenvolvimento econômico sustentável da cidade em cumprimento a sua função social.

Palavras-chave: cidades- lei -urbanismo- desenvolvimento sustentável

\begin{abstract}
Urban Law after the advent of the Federal Constitution of 1988 has gained importance in the study of law that intensified with the publication of Law no. 10.257/2001Statute Cidade.Tomando as parameter models medium to urban cities like that technique to be adopted by a significant portion of Brazilian municipalities director post on your plan, you create a new profile territories, promoting the integration between spaces urban and rural and sustainable economic development of the city in fulfillment of its social function.
\end{abstract}

Keywords: sustainable cities-law-urbanism-development

\footnotetext{
${ }^{1}$ Advogado e Professor. Membro do Instituto dos Advogados Brasileiros - IAB. Doutor em Direito pela Universidade do Estado do Rio de Janeiro - UERJ. Mestre em Direito Civil pela Universidade do Estado do Rio de Janeiro - UERJ. Professor convidado da Pós-Graduação Lato Sensu do CEPED-UERJ (Direito Imobiliário, Direito da Propriedade Intelectual, Direito da Empresa).
} 


\section{Introdução:}

O presente estudo tem por objetivo investigar o novo papel do Direito Urbanístico após o advento da Constituição Federal de 1988 e os seus sentidos estabelecidos no Estatuto da Cidade (Lei n. 10.257/2001). Em seguida, apontaremos o modelo da cidademédia como aquela técnica urbanística a ser adotada por parcela representativa dos Municípios brasileiros em seu plano diretor posto que, através desse novo recorte territorial, melhor se promoverá os postulados da integração entre os espaços urbano e rural e do desenvolvimento econômico sustentável da cidade em cumprimento a sua função social.

Para tanto, empregaremos o método civil-constitucional ${ }^{2}$, que consiste na compreensão de um sistema fundado nos valores presentes no ordenamento jurídico vigente a privilegiar a função dos institutos jurídicos ao invés dos esquemas meramente formais vazios da fattispecie isoladamente considerados em si mesmos, e que promove, ao lado do primado da lei, outros componentes culturais axiológicos, que devem atuar na efetivação do valor supremo da dignidade da pessoa humana.

\section{A constitucionalização do Direito Urbanístico: a dignidade da pessoa humana como vetor axiológico unificador do ordenamento jurídico.}

A evolução do Direito Urbanístico é acentuada tanto no direito comparado ${ }^{3}$ como no direito brasileiro.

No âmbito do direito brasileiro, Hely Lopes Meirelles ${ }^{4}$ concebeu o Direito Urbanístico como "o conjunto de medidas estatais destinadas a organizar os espaços habitáveis, de modo a propiciar melhores condições de vida ao homem na comunidade". Estes espaços habitáveis, ainda segundo Hely Lopes Meirelles, são compreendidos como "todas as áreas em que o homem exerce coletivamente qualquer das quatro funções sociais: habitação, trabalho, circulação, recreação". Conclui o autor que o urbanismo

\footnotetext{
${ }^{2}$ PERLINGIERI, Pietro. Perfis de Direito Civil - Introdução ao Direito Civil Constitucional. Rio de Janeiro: Renovar, 1999, p. 156.

3 Consulte-se, por todos, ANTUNES, Luis Filipe Colaço. Direito Urbanístico. Um outro paradigma: A Planificação Modesto-Situacional. Coimbra: Almedina, 2002, p. 70.

${ }^{4}$ MEIRELLES, Hely Lopes. Direito Municipal Brasileiro. 11. ed. São Paulo: Malheiros, 2000, p. 433.
} 
"é incumbência de todos os níveis de governo e se estende a todas as áreas da cidade e do campo, onde as realizações humanas ou a preservação da natureza possam contribuir para o bem-estar individual e coletivo. Mas, como nas cidades se concentram populações, suas áreas exigem mais e maiores empreendimentos urbanísticos, visando a oferecer o maior bem para o maior número - objetivo supremo do moderno Urbanismo".

Já Diogo de Figueiredo Moreira Neto ${ }^{5}$ define o Direito Urbanístico como "o conjunto da disciplina jurídica notadamente de natureza administrativa, incidente sobre os fenômenos do Urbanismo, destinado ao estudo das normas que visem impor valores $e$ convivências na ocupação e utilização dos espaços habitáveis".

Defendendo a sua autonomia em relação ao direito administrativo, José Afonso da Silva ${ }^{6}$ conceitua o Direito Urbanístico, sob o prisma objetivo, como "o conjunto de normas que têm por objetivo organizar os espaços habitáveis", através da intervenção do Poder Público, que visa "propiciar melhores condições de vida ao homem na cidade".

Das definições reproduzidas acima, verifica-se que os contornos do Direito Urbanístico estão intimamente relacionados à cidade e às necessidades conexas com o estabelecimento humano nela. Pode-se, assim, dizer que o urbanismo evolui com a cidade.

Em virtude dos influxos políticos e sócio-econômicos da segunda metade do século XX, esse centro populacional urbano ${ }^{7}$ cresceu em proporção superior à população rural, gerando graves e sérios problemas cuja solução demanda a ordenação e a correção dos espaços habitáveis por meio de um planejamento adequado com vistas a assegurar a preservação do meio ambiente natural e cultural e o desenvolvimento sustentável econômico-

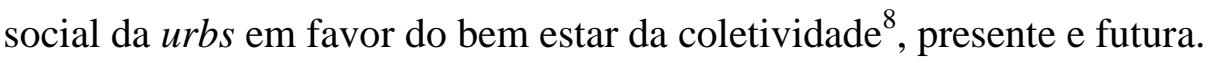

\footnotetext{
${ }^{5}$ NETO MOREIRA, Diogo de Figueiredo. Introdução ao Direito Ecológico e ao Direito Urbanístico. 2. ed. Rio de Janeiro: Forense, 1977, p. 46.

${ }^{6}$ SILVA, José Afonso da. Direito Urbanístico Brasileiro. 5. ed. São Paulo: Malheiros, 2008, p. 49.

7 SILVA, José Afonso da. Op. Cit.,, p. 19-27: "Enfim, do ponto de vista urbanístico, um centro populacional assume característica de cidade quando possui dois elementos essenciais: (a) as unidades edilícias - ou seja, o conjunto de edificações em que os membros da coletividade moram ou desenvolvem suas atividades produtivas, comerciais, industriais ou intelectuais; 9b) os equipamentos públicos - ou seja, os bens públicos e sociais criados para servir às unidades edilícias e destinados à satisfação das necessidades de que os habitantes não podem prover-se diretamente e por sua própria conta (estrada, ruas, praças, parques, jardins, canalização subterrânea, escolas, igrejas, hospitais, mercados, praças de esportes, etc.). (...) A urbanização gera enormes problemas. Deteriora o ambiente urbano. Provoca a desorganização social, com carência de habitação, desemprego, problemas de higiene e de saneamento básico. Modifica a utilização do solo e transforma a paisagem urbana".

8 Expressão tomada numa acepção ampla para albergar direitos difusos e coletivos, espécies do gênero transindividual. A garantia do direito a cidades sustentáveis para as gerações presentes e futuras está assegurada no artigo $2^{\circ}$, I, da Lei n. 10.257/01 (Estatuto da Cidade).
} 
O Direito Urbanístico foi recentemente alçado pela Constituição Federal de 1988 como uma disciplina autônoma ${ }^{9}$, dispensando-lhe o próprio legislador constituinte tratamento específico.

Dessa forma, foram traçadas normas de competência em favor da União, dos Estados e dos Municípios, facultando-lhes o estabelecimento de regramento sobre o urbanismo (artigos 21, IX, XX e XXI; 24, I; 30, I, II, VIII e IX, da CF).

Também foram consagradas normas sobre a política do desenvolvimento urbano $^{10}$ e a ordenação do pleno desenvolvimento das funções da cidade e da garantia do bem-estar dos seus habitantes, da propriedade urbana e a sua função social, a desapropriação dos imóveis urbanos, bem como mecanismos para o adequado aproveitamento do solo urbano (artigos 30, VIII, 182 e 183, da CF), e, ainda, proteção à paisagística, artística e histórica $\left(\operatorname{artigos} 30, \mathrm{IX} ; 215\right.$ e 216 , da CF) ${ }^{11}$.

No direito urbanístico são tutelados interesses e direitos transindividuais ${ }^{12}$, notadamente os difusos ${ }^{13}$. Isto porque a localização da cidade, a sua extensão, a sua configuração e a sua magnitude não são e não podem ser realizações privadas, mas, sim, realizações públicas porquanto interessam à coletividade, condicionando a vida comunitária e a pessoa de todos os membros da comunidade no espaço urbano ${ }^{14}$.

\footnotetext{
${ }^{9}$ LIRA, Ricardo Pereira. Direito Urbanístico, Estatuto da Cidade e Regularização Fundiária. In Direito da Cidade. Novas Concepções sobre as Relações Jurídicas no Espaço Social Urbano. Rio de Janeiro: Lúmen Júris, 2007, p. 5: "a autonomia do Direito Urbanístico deita suas raízes no próprio Direito Constitucional".

${ }_{10}$ VICHI, Bruno de Souza, Política Urbana. Sentido jurídico, competências e responsabilidades. Belo Horizonte: Fórum, 2007.

${ }^{11}$ Veja-se, entre outros, MACHADO, Paulo Affonso Leme. Direito Ambiental Brasileiro. 16. ed. São Paulo: Malheiros, 2008, p. 929-945.

${ }^{12}$ A propósito da definição de interesses ou direitos transindividuais, remetemos ao artigo 81 da Lei n. 8.078/90: "Art. 81. A defesa dos interesses e direitos dos consumidores e das vítimas poderá ser exercida em juízo individualmente, ou a título coletivo. Parágrafo único. A defesa coletiva será exercida quando se tratar de: I interesses ou direitos difusos, assim entendidos, para efeitos deste código, os transindividuais, de natureza indivisível, de que sejam titulares pessoas indeterminadas e ligadas por circunstâncias de fato; II - interesses ou direitos coletivos, assim entendidos, para efeitos deste código, os transindividuais, de natureza indivisível de que seja titular grupo, categoria ou classe de pessoas ligadas entre si ou com a parte contrária por uma relação jurídica base".

${ }^{13}$ CAVALAZZI, Rosangela Lunardelli. O Estatuto Epistemológico do Direito Urbanístico Brasileiro: possibilidades e obstáculos na tutela do direito à cidade. In Direito da Cidade. Novas Concepções sobre as Relações Jurídicas no Espaço Social Urbano. Rio de Janeiro: Lúmen Júris, 2007, p. 57: “(...) como direito humano na categoria dos interesses difusos".

${ }^{14}$ LIRA, Ricardo Pereira. Elementos de Direito Urbanístico. Rio de Janeiro: Renovar, 1997, p. 371.
} 
A Constituição é norma fundamental que confere unidade e coerência ao sistema jurídico $^{15}$. Sobre essas qualidades da norma fundamental, ensina Noberto Bobbio ${ }^{16}$ que

\begin{abstract}
"dado o poder constituinte como poder último, devemos pressupor, portanto, uma norma que atribua ao poder constituinte a faculdade de produzir normas jurídicas, essa norma é a norma fundamental. (...). Posto um ordenamento de normas de diversas procedências, a unidade do ordenamento postula que as normas que o compõem sejam unificadas. (...) Essa norma única não pode ser senão aquela que impõe obedecer ao poder originário do qual deriva a Constituição, que dá origem às leis ordinárias, que por sua vez, dão origem aos regulamentos, decisões judiciárias, etc.".
\end{abstract}

A Carta de 1998 trouxe uma nova realidade da dogmática constitucional, o neoconstitucionalismo ou pós-positivismo ${ }^{17}$, consagrando a dignidade da pessoa humana como o primeiro dos direitos fundamentais (artigo $1^{\circ}$, III, da CF). A sua posição topológica no texto da Carta Constitucional revela, a um só tempo, o seu superior status principiológico, como alicerce central dos objetivos a serem implantados pelo Estado, e a sua função de vetor axiológico. Ressaltando a dignidade da pessoa humana como o princípio fundamental e o valor supremo de alicerce do nosso ordenamento jurídico, assevera Maria Celina Bodin de Moraes $^{18}$.

“... a Constituição democrática de 1988 explicitou, no art. 1', III, a dignidade da pessoa humana como um dos 'fundamentos da República'. A dignidade humana, então, não é criação da ordem constitucional, embora seja por ela respeitada e protegida. A Constituição consagrou o princípio e, considerando a sua eminência, proclamou-o entre os princípios fundamentais, atribuindo-lhe o valor supremo de alicerce da ordem jurídica democrática”.

\footnotetext{
${ }^{15}$ ENTERRÍA, Eduardo García de. La Constitución como Norma y el Tribunal Constitucional. Madrid: Civitas, 1994, p. 95: "La supremacía de la Constitución sobre todas las normas y su caráter central em la construcción y em la validez del ordenamiento em su conjunto, obligan a intepretar este em cualquier momento de su aplicación - por operadores públicos o por operados privados, por Tribunales o por órganos legislativos o administrativos em el sentido que resulta de los princípios y reglas constitucionales, tanto los generales como los específicos referentes a la matéria de que se trate".

${ }^{16}$ BOBBIO, Norberto. Teoria do Ordenamento Jurídico. trad. Maria Celeste Cordeiro Leite dos Santos. 10. ed., Brasília: UnB, 1999, p. 58-59.

${ }^{17}$ MAIA, Antônio Cavalcanti. As Transformações dos Sistemas Jurídicos Contemporâneos: Apontamentos acerca do neoconstitucionalismo. In Revista de Direito do Estado, ${ }^{\circ}$ 5, janeiro/março, 2007, p. 244-245: "Estas transformações impuseram à nossa dogmática constitucional a necessidade de elaboração de uma nova referência: o pós-positivismo, situando assim o pensamento jurídico contemporâneo para além da estiolada querela jusnaturalismo versus positivismo jurídico. (...) Eis que esta nova realidade jurídico-constitucional que ensejou o surgimento da categoria da categoria pós-positivista em nosso âmbito cultural vem sendo denominada nas doutrinas espanhola e italiana neoconstitucionalismo".

${ }_{18}$ MORAES, Maria Celina Bodin de. O Princípio da Dignidade Humana. In Princípios do Direito Civil Contemporâneo. Rio de Janeiro: Renovar, 2006, p. 14.
} 
Como se vê, o legislador constituinte privilegiou, prima facie, os valores nãopatrimoniais para os quais se devem voltar às situações jurídicas patrimoniais ${ }^{19}$. Nesse aspecto, pontifica Pietro Perlgingieri ${ }^{20}$ que "não existe um número fechado de hipóteses tuteladas: tutelado é o valor da pessoa sem limites, salvo aqueles colocados no seu interesse e naqueles de outras pessoas".

Em vista desse novel cenário metodológico da constitucionalização dos diversos ramos dos direitos - em especial a do Direito Urbanístico e os direitos transindividuais a ele relacionados-, deve-se atentar para o vetor axiológico da dignidade da pessoa humana como núcleo central de um sistema composto por um feixe de interesses e direitos sociais, em rol exemplificativo, como a moradia, educação, trabalho, saúde, serviços e transportes públicos, patrimônio cultural, meio-ambiente natural, etc.

Acerca dos direitos sociais, notadamente a moradia e o lazer, Regis Fernandes de Oliveira ${ }^{21}$ registra que "a Constituição, já em seu preâmbulo, estabelece que o Estado democrático é destinado a garantir 'a segurança, o bem-estar, o desenvolvimento, a igualdade e a justiça como valores supremos de uma sociedade fraterna, pluralista e sem preconceitos"”.

Nesse mesmo sentido, observa Márcio Cammarosano que se

"não se proporcionam condições de moradia decadente ao trabalhador e à sua família desrespeita-se a dignidade da pessoa humana, fundamento da República Federativa do Brasil (CF, art. 1 ${ }^{\circ}$, III) e se deixa de prestigiar o art. $3^{\circ}$, III, da Constituição, que estabelece como um dos objetivos fundamentais da República erradicar a pobreza e a marginalização e reduzir as desigualdades sociais e regionais" 22 .

A chamada crise da dicotomia rígida entre o direito público e o direito privado gerada por essa constitucionalização encontra a sua solução no postulado da dignidade da pessoa que se apresenta num ponto de confluência de interesses públicos e de interesses privados, de direitos transindividuais e direitos individuais. Deveras, é impositiva a releitura

\footnotetext{
19 TEPEDINO, Gustavo. Premissas Metodológicas para a Constitucionalização do Direito Civil. In Temas de Direito Civil. Rio de Janeiro: Renovar, 1999, p. 22.

${ }^{20}$ Op. Cit., p. 156.

${ }^{21}$ OLIVEIRA, Regis Fernandes. Comentários ao Estatuto da Cidade. 2. ed. São Paulo: R.T., 2005, p. 14.

${ }^{22}$ CAMMAROSANO, Márcio. Fundamentos constitucionais do Estado da Cidade. In. Estatuto da Cidade (Comentários à Lei Federal 10.257/2001). 2. ed. Coordenadores DALLARI, Adilson Abreu, FERRAZ, Sérgio. São Paulo: Malheiros, 2006, p. 24.
} 
da summa divisio público-privado ${ }^{23}$, e, por via de consequiência, dos inúmeros institutos jurídicos, como a propriedade urbana ${ }^{24}$ e a sua inserção na cidade, que é disciplinada pelo Direito Urbanístico, cujo conteúdo, com evidente função pública, pressupõe interesses e fins coletivos e atuação do Poder Público por meio de normas positivas, negativas e permissivas.

A este respeito, Elida Séguin ${ }^{25}$ assim as define e traz os seguintes exemplos:

"positivas, que forçam o particular a fazer determinada coisa, v.g., a obrigatoriedade do proprietário do terreno urbano não construído de mantê-lo cercado e capinado; negativas, que impedem o particular de fazer algo, v.g., a proibição de construir de maneira que tape a visão do prédio tombado pelo Instituto do Patrimônio Histórico-Artístico nacional (IPHAN); e permissiva, que deixa fazer, como a norma instituída no art. 572 do Código Civil de 1916 que permitia o proprietário levantar em seu terreno as construções que lhe aprouvesse, salvo o direito de vizinho e os regulamentos administrativos".

O conceito do direito de propriedade foi alterado pelo art. 1.228 do Código Civil1 $^{26}$ em vigor, que é reconhecido, “como qualidade intrínseca, uma função social, fundada e justificada precisamente pelo princípio da destinação universal dos bens" ${ }^{27}$.

\section{O novo papel do Direito Urbanístico e a sua relação com os demais ramos do Direito.}

Com o advento da Constituição de 1988, o papel do Direito Urbanístico, nas palavras de Carlos Ari Sundfeld ${ }^{28}$, é o de "servir à definição e implementação 'da política de desenvolvimento', a qual tem por finalidade 'ordenar o pleno desenvolvimento das funções sociais da cidade e garantir o bem-estar de seus habitantes".

\footnotetext{
${ }^{23}$ GIORGIANNI, Michelli. Direito Privado e as suas atuais fronteiras. In Revista dos Tribunais, São Paulo, vol. 747, jan. 1998, p. 55. NEGREIROS, Teresa. Dicotomia Público-Privado frente ao Problema da Colisão de Princípios. In Teoria dos Direitos Fundamentais. Org. Ricardo Lobo Torres. Rio de Janeiro: Renovar, 1999, p. 340 e 372.

${ }^{24}$ Acerca da releitura da propriedade urbana imóvel, consulte-se, por todos, TORRES, Marcos Alcino de Azevedo. Instrumentos Urbanísticos e a Propriedade Urbana Imóvel. In TEPEDINO, Gustavo (Coord.). Problemas de Direito Civil-Constitucional. Rio de Janeiro: Renovar, 2000, p. 467-473.

${ }^{25}$ SÉGUIN, Elida. Estatuto da Cidade. 2. ed. Rio de Janeiro: Forense, 2005, p. 35.

${ }^{26} \mathrm{CC}$, Art. 1.228. O proprietário tem a faculdade de usar, gozar e dispor da coisa, e o direito de reavê-la do poder de quem quer que injustamente a possua ou detenha. $\S 1^{\mathrm{o}} \mathrm{O}$ direito de propriedade deve ser exercido em consonância com as suas finalidades econômicas e sociais e de modo que sejam preservados, de conformidade com o estabelecido em lei especial, a flora, a fauna, as belezas naturais, o equilíbrio ecológico e o patrimônio histórico e artístico, bem como evitada a poluição do ar e das águas. $§ 2^{\underline{0}}$ São defesos os atos que não trazem ao proprietário qualquer comodidade, ou utilidade, e sejam animados pela intenção de prejudicar outrem.

${ }^{27}$ MOTA, Maurício. Questões de Direito Civil Contemporâneo. Rio de Janeiro: Elsevier, 2008, p. 589: "Portanto, o direito de propriedade não é um absoluto formal, mas só se justifica se a ele é dado um uso social e na medida dessa justificação, mormente naquela classe de bens que não se destina primordialmente ao mercado, como é o caso da terra".

${ }^{28}$ SUNDFELD, Carlos Ari. O Estatuto da Cidade e as suas diretrizes gerais. In DALLARI, Adilson Abreu, FERRAZ, Sérgio (Coord.). Estatuto da Cidade (Comentários à Lei Federal 10.257/2001). 2. ed.. São Paulo: Malheiros, 2006, p. 48.
} 


\title{
O artigo 182 da Constituição Federal $^{29}$ anuncia o Direito Urbanístico como
}

direito da política de desenvolvimento urbano, em três sentidos:

“a) como conjunto das normas que disciplinam a fixação dos objetivos da política urbana (exemplo: normas constitucionais); b) como conjunto de textos normativos em que estão fixados os objetivos da política urbana (os planos urbanísticos, por exemplo); c) como conjunto de normas em que estão previstos e regulados os instrumentos de implementação da política urbana (o próprio Estatuto da Cidade, entre outros)" 30 .

A partir dessa nova e relevante perspectiva na implantação das funções sociais da cidade é imprescindível que se abra espaço para um novo diálogo na busca de novas ações, instrumentos e mecanismos fundamentais e práticas para promover o bem-estar social e a sustentabilidade das cidades com ramos do Direito Civil, Econômico, Processual Civil, Comunitário, Penal, Tributário, etc. ${ }^{31} 3233$

A título de ilustração, fala-se, assim, em um Direito Civil Urbanístico, por meio do qual se estabelece um elo entre o direito civil, notadamente após o advento do Código Civil de 2002, e o Direito Urbanístico. Nesse sentido, confira-se a lição de Luigi Bonizzato:

\begin{abstract}
"Originariamente, sempre se estabeleceram como ele entre o direito civil e o direito urbanístico as normas relativas aos direitos de vizinhança e, posteriormente, ao próprio direito de propriedade. Entretanto, a nova codificação civil de 2002 trouxe à tona outros institutos, os quais com o direito urbanístico detém íntima relação, tais como o direito da superfície, para o qual também se dedica uma seção específica do Estatuto da Cidade. (...), dedicar-se-á atenção direcionada para os preceitos civil relacionados à fraude à lei e ao abuso de direito".
\end{abstract}

\footnotetext{
${ }^{29}$ Da Política Urbana. Art. 182. A política de desenvolvimento urbano, executada pelo Poder Público municipal, conforme diretrizes gerais fixadas em lei, tem por objetivo ordenar o pleno desenvolvimento das funções sociais da cidade e garantir o bem-estar de seus habitantes. $\S 1^{\circ}$ - O plano diretor, aprovado pela Câmara Municipal, obrigatório para cidades com mais de vinte mil habitantes, é o instrumento básico da política de desenvolvimento e de expansão urbana. $\S 2^{\circ}$ - A propriedade urbana cumpre sua função social quando atende às exigências fundamentais de ordenação da cidade expressas no plano diretor. $\S 3^{\circ}$ - As desapropriações de imóveis urbanos serão feitas com prévia e justa indenização em dinheiro. $\S 4^{\circ}$ - É facultado ao Poder Público municipal, mediante lei específica para área incluída no plano diretor, exigir, nos termos da lei federal, do proprietário do solo urbano não edificado, subutilizado ou não utilizado, que promova seu adequado aproveitamento, sob pena, sucessivamente, de: I - parcelamento ou edificação compulsórios; II - imposto sobre a propriedade predial e territorial urbana progressivo no tempo; III - desapropriação com pagamento mediante títulos da dívida pública de emissão previamente aprovada pelo Senado Federal, com prazo de resgate de até dez anos, em parcelas anuais, iguais e sucessivas, assegurados o valor real da indenização e os juros legais.

${ }^{30}$ SUNDFELD, Carlos Ari. Op. Cit., p. 49.

${ }^{31}$ SILVA, José Afonso da. Op. Cit., p. 48-49. SÉGUIN, Élida. Op. Cit., p. 36-47.

${ }^{32}$ Autor ???? Propriedade Urbana Privada \& Direitos Sociais. Curitiba: Juruá, 2007, p. 115: “’”.

${ }^{33}$ Veja-se, também, sob o aspecto ambiental, MOREIRA, Bruno, MARANGONI, Marina, CASTILHO, Rafael. As áreas de Proteção Ambiental e os Impostos sobre a Propriedade. In ORLANDO, Breno Ladeira Kingma, GUDIÑO, Daniel Mariz, TROUW, Ernesto Johannes, GONÇALVES, Fábio Fraga, MUNIZ, Igor, MURAYAMA, Janssen Hiroshi (Coord.). Direito Tributário Ambiental. Rio de Janeiro: Lúmen Júris, 2008, p. $161-177$
} 


\section{Direito Urbanístico: o Estatuto da Cidade (Lei n. 10. 257/2001) e as suas diretrizes gerais.}

Ao Estatuto da Cidade, instituído pela Lei n. 10.257/2001, coube regulamentar os artigos 182 e 183 da Constituição Federal e estabelecer as diretrizes gerais da política urbana.

Essas diretrizes são normas gerais estabelecidas pela União. De acordo com Luís Roberto Barroso ${ }^{34}$, a norma geral é aquela que está "sujeita a elevado grau de indeterminação" e "tem por objeto princípios e questões fundamentais, tratados em termos esquemáticos, não sendo próprio a norma dessa natureza cuidar de pormenores ou esgotar o tema que está sendo versado".

O Estatuto da Cidade é um do pilares do Direito Urbanístico que contém relevantes instrumentos para implantação das funções sociais da cidade e da propriedade urbana ${ }^{35}$. O seu objetivo precípuo foi de ordenar o pleno desenvolvimento das funções sociais da cidade e garantir o bem-estar dos seus habitantes (artigo 182 da CF).

Entre os postulados estabelecidos no Estatuto da Cidade com objetivo de nortear os legisladores e os administradores ${ }^{36}$, destacam-se para o escopo do presente estudo (i) a garantia do direito às cidades sustentáveis, entendido como o direito à terra urbana, à moradia, ao saneamento ambiental, à infra-estrutura urbana, ao transporte e aos serviços públicos, ao trabalho e ao lazer, para as presentes e futuras gerações, (ii) a integração e complementariedade entre as atividades urbanas e rurais, tendo em vista o desenvolvimento econômico do Município e do território sob a sua área de influência e (iii) a cooperação entre os governos, a iniciativa privada e os demais setores da sociedade no processo de urbanização, em atendimento ao interesse social e (artigo $2^{\circ}$, I, III e VII).

\footnotetext{
${ }^{34}$ BARROSO, Luís Roberto. Temas de Direito Constitucional. 2. ed. Rio de Janeiro: Renovar, 2002, p. 188.

${ }^{35}$ LIRA, Ricardo Pereira. Op. Cit., p. 6-7.

${ }^{36}$ FILHO, José dos Santos Carvalho. Comentários ao Estatuto da Cidade. Rio de Janeiro: Lúmen Júris, 2005, p. 20-21: "Diretrizes gerais da política pública são o conjunto de situações urbanísticas de fato e de direito a serem alvejadas a ordem urbanística, de modo a assegurar o bem-estar das comunidades em geral".
} 
No âmbito do Estatuto da Cidade, a atividade de ordenação dos espaços urbanos deve ser dirigida à promoção do triplo objetivo de humanização, ordenação e harmonização dos ambientais em que o homem vive: o urbano e o rural ${ }^{37}$.

Amplia-se, assim, o objeto do Direito Urbanístico que passa a ser "o estudo $e$ formulação de princípios, normas e políticas públicas que devem reger os espaços habitáveis no seu conjunto cidade-campo" 38 . Desse modo, a política urbana deve buscar harmonizar-se com a política agrícola, de sorte que ambas deverão ser conjugadas, cada vez mais, com o Direito Ambiental ${ }^{39}$ na implantação das diretrizes gerais com vistas ao bem-estar da comunidade (artigo $2^{\circ}$ da Lei n. $\left.10.257 / 2001\right)^{40}$.

\footnotetext{
${ }^{37}$ SILVA, José Afonso. Op. Cit., p. 34.

${ }^{38}$ SÉGUIN, Elida. Op. Cit., p. 33.

${ }^{39}$ SILVA, José Afonso da. Direito Ambiental Constitucional. 6. ed. São Paulo: Malheiros, 2008, p. 224-225.
}

${ }^{40}$ Art. $2^{\mathrm{O}}$ A política urbana tem por objetivo ordenar o pleno desenvolvimento das funções sociais da cidade e da propriedade urbana, mediante as seguintes diretrizes gerais: I - garantia do direito a cidades sustentáveis, entendido como o direito à terra urbana, à moradia, ao saneamento ambiental, à infra-estrutura urbana, ao transporte e aos serviços públicos, ao trabalho e ao lazer, para as presentes e futuras gerações; II - gestão democrática por meio da participação da população e de associações representativas dos vários segmentos da comunidade na formulação, execução e acompanhamento de planos, programas e projetos de desenvolvimento urbano; III - cooperação entre os governos, a iniciativa privada e os demais setores da sociedade no processo de urbanização, em atendimento ao interesse social; IV - planejamento do desenvolvimento das cidades, da distribuição espacial da população e das atividades econômicas do Município e do território sob sua área de influência, de modo a evitar e corrigir as distorções do crescimento urbano e seus efeitos negativos sobre o meio ambiente; V - oferta de equipamentos urbanos e comunitários, transporte e serviços públicos adequados aos interesses e necessidades da população e às características locais; VI - ordenação e controle do uso do solo, de forma a evitar: a) a utilização inadequada dos imóveis urbanos; b) a proximidade de usos incompatíveis ou inconvenientes; c) o parcelamento do solo, a edificação ou o uso excessivos ou inadequados em relação à infraestrutura urbana; d) a instalação de empreendimentos ou atividades que possam funcionar como pólos geradores de tráfego, sem a previsão da infra-estrutura correspondente; e) a retenção especulativa de imóvel urbano, que resulte na sua subutilização ou não utilização; f) a deterioração das áreas urbanizadas; g) a poluição e a degradação ambiental; VII - integração e complementaridade entre as atividades urbanas e rurais, tendo em vista o desenvolvimento socioeconômico do Município e do território sob sua área de influência;VIII - adoção de padrões de produção e consumo de bens e serviços e de expansão urbana compatíveis com os limites da sustentabilidade ambiental, social e econômica do Município e do território sob sua área de influência; IX - justa distribuição dos benefícios e ônus decorrentes do processo de urbanização; $\mathrm{X}$ - adequação dos instrumentos de política econômica, tributária e financeira e dos gastos públicos aos objetivos do desenvolvimento urbano, de modo a privilegiar os investimentos geradores de bem-estar geral e a fruição dos bens pelos diferentes segmentos sociais; XI - recuperação dos investimentos do Poder Público de que tenha resultado a valorização de imóveis urbanos; XII - proteção, preservação e recuperação do meio ambiente natural e construído, do patrimônio cultural, histórico, artístico, paisagístico e arqueológico; XIII - audiência do Poder Público municipal e da população interessada nos processos de implantação de empreendimentos ou atividades com efeitos potencialmente negativos sobre o meio ambiente natural ou construído, o conforto ou a segurança da população; XIV - regularização fundiária e urbanização de áreas ocupadas por população de baixa renda mediante o estabelecimento de normas especiais de urbanização, uso e ocupação do solo e edificação, consideradas a situação socioeconômica da população e as normas ambientais; XV - simplificação da legislação de parcelamento, uso e ocupação do solo e das normas edilícias, com vistas a permitir a redução dos custos e o aumento da oferta dos lotes e unidades habitacionais; XVI - isonomia de condições para os agentes públicos e privados na promoção de empreendimentos e atividades relativos ao processo de urbanização, atendido o interesse social. 
O Estatuto da Cidade permite a utilização de outros instrumentos além daqueles previstos o seu artigo $4^{\circ}$, cujo rol é exemplificativo ${ }^{41}$. A propósito, cite-se lição de Celso Pacheco Fiorillo ${ }^{42}$ :

"para fins previstos no Estatuto da Cidade, a saber, na execução da política urbana vinculada ao objetivo de ordenar a cidade em proveito da dignidade da pessoa humana, a Lei 10.257/2001 estabeleceu alguns instrumentos, dentre outros, exatamente com a finalidade de fazer com que o diploma se efetive no sentido de organizar as necessidades de brasileiros e estrangeiros aqui residentes dentro da ordem econômica capitalista".

\section{A integração e a sustentabilidade entre os espaços urbanos e dos espaços rurais como função social da Cidade.}

A integração do campo-cidade é um imperativo indeclinável na política urbana, que impede raciocinar-se e agir em termos de separação rígida entre o espaço urbano e o espaço rural. As fronteiras se flexibilizaram, as atividades se integram e se complementam, pois o urbano e o rural fazem parte do território do Município ${ }^{43}$.

Cumpre, então, ao urbano estar atento ao rural, e dele não se olvidar. A política pública urbana deve direcionar-se no sentido de promover a integração entre a cidade e o campo, levando em conta o setor rural e as peculiaridades que lhe são próprias.

\footnotetext{
${ }^{41}$ Art. 4ํㅗ Para os fins desta Lei, serão utilizados, entre outros instrumentos: I - planos nacionais, regionais e estaduais de ordenação do território e de desenvolvimento econômico e social; II - planejamento das regiões metropolitanas, aglomerações urbanas e microrregiões; III - planejamento municipal, em especial: a) plano diretor; b) disciplina do parcelamento, do uso e da ocupação do solo; c) zoneamento ambiental; d) plano plurianual; e) diretrizes orçamentárias e orçamento anual; f) gestão orçamentária participativa; g) planos, programas e projetos setoriais; h) planos de desenvolvimento econômico e social; IV - institutos tributários e financeiros: a) imposto sobre a propriedade predial e territorial urbana - IPTU; b) contribuição de melhoria; c) incentivos e benefícios fiscais e financeiros; $\mathrm{V}$ - institutos jurídicos e políticos: a) desapropriação; b) servidão administrativa; c) limitações administrativas; d) tombamento de imóveis ou de mobiliário urbano; e) instituição de unidades de conservação; f) instituição de zonas especiais de interesse social; g) concessão de direito real de uso; h) concessão de uso especial para fins de moradia; i) parcelamento, edificação ou utilização compulsórios; j) usucapião especial de imóvel urbano; 1) direito de superfície; m) direito de preempção; n) outorga onerosa do direito de construir e de alteração de uso; o) transferência do direito de construir; p) operações urbanas consorciadas; q) regularização fundiária; r) assistência técnica e jurídica gratuita para as comunidades e grupos sociais menos favorecidos; s) referendo popular e plebiscito; VI - estudo prévio de impacto ambiental (EIA) e estudo prévio de impacto de vizinhança (EIV) $\S 1^{\circ}$ O Os instrumentos mencionados neste artigo regem-se pela legislação que lhes é própria, observado o disposto nesta Lei. $\S 2^{\underline{0}}$ Nos casos de programas e projetos habitacionais de interesse social, desenvolvidos por órgãos ou entidades da Administração Pública com atuação específica nessa área, a concessão de direito real de uso de imóveis públicos poderá ser contratada coletivamente. $\S 3^{\circ}$ Os instrumentos previstos neste artigo que demandam dispêndio de recursos por parte do Poder Público municipal devem ser objeto de controle social, garantida a participação de comunidades, movimentos e entidades da sociedade civil.

${ }^{42}$ FIORILLO, Celso Pacheco. Estatuto da Cidade Comentado. 3. ed. São Paulo: R.T., 2008, p. 81.

${ }^{43}$ MEDAUAR, Odete. Estatuto da Cidade. Comentários. 2. ed. São Paulo: R.T., 2004, p. 34.
} 
O setor rural produz artigos agrícolas, alimentícios, laticínios direcionados ao setor urbano, no qual, por sua vez, estão localizados os setores industrial, comercial e de prestação de serviços mais desenvolvidos. Não se pode, pois, conceber a idéia de considerálos - urbano (cidade) e rural (campo) -, em separados, mas, sim, é necessário promover a integração entre as atividades urbanas e rurais, harmonizando e compatibilizando-as. Tal exigência impõe ao Poder Público o dever de promover ações com vistas a estreitar as relações sociais e econômicas entre o campo e a cidade, notadamente nas áreas de influência desta ${ }^{44}$, através das técnicas e dos instrumentos da ciência urbanística no planejamento da cidade, disciplinando o seu crescimento e suprindo as necessidades básicas do homem ${ }^{45}$.

Somente, assim, se poderá, concretamente, implementar a integração urbanorural necessária à função social da Cidade com vistas ao bem-estar da coletividade.

Nessa esteira, o grupo formado por membros do Ministério do Meio Ambiente/Ibama/Consórcio 21 IBAM/ Iser/ Redeh, baseando-se nos princípios da Agenda 21 e Agenda Habitat, dos tratados internacionais dos quais o Brasil é signatário, da Constituição de 1988 e da legislação infraconstitucional, concebeu 04 (quatro) estratégias para a sustentabilidade urbana como sendo prioritárias para o desenvolvimento sustentável das cidades brasileiras ${ }^{46}$.

Pontuou-se, entre elas, a promoção do desenvolvimento institucional e o fortalecimento da capacidade de planejamento e gestão democrática da cidade, incorporando no processo a dimensão ambiental urbana e assegurando a efetiva participação da sociedade, por meio da "integração entre as políticas urbanas e rurais, visando a complementariedade das atividades e a redução dos impactos ambientais provocados nessas duas esferas, seja pelos perfis de produção e consumo, pela poluição e contaminação geradas ou pelos fluxos de população".

Além da colaboração entre governos, uma eficiente integração entre as dimensões urbana e rural pressupõe, também, a participação da iniciativa privada e dos demais setores da sociedade no processo de transformação da cidade, em atendimento ao interesse social, consoante o disposto na diretriz prevista no artigo $2^{\circ}$, VII, do Estatuto da Cidade. Nesse contexto, vale salientar, ainda, o relevante papel da iniciativa privada e das

\footnotetext{
${ }^{44}$ FILHO, JOSÉ DOS SANTOS CARVALHO. Op. Cit., p. 29-30.

${ }^{45}$ SÉGUIN, Élida. Estatuto da Cidade. 2. ed. Rio de Janeiro: Forense, 2005, p. 12

${ }^{46}$ VIEIRA, Juliana de Souza Reis. Cidades Sustentáveis. In MOTA, Mauricio (Coord.) Fundamentos Teóricos do Direito Ambiental. São Paulo: Elsevier, 2008, p. 337.
} 
entidades da sociedade também na gestão democrática da cidade, através dos mecanismos criados pelo Estatuto da Cidade ${ }^{47}$.

Deveras, a propriedade urbana não pode ficar ociosa, sem destinação específica ou ainda sem qualquer utilização, e o interesse do particular (proprietário) ${ }^{48}$ cede lugar para o interesse público transindividual urbanístico ${ }^{49}$, que, por sua vez, deve promover uma interseção público / privado $^{50}$, com vistas ao atendimento das necessidades, coletivas e particulares, dos cidadãos quanto à implementação da justiça ${ }^{51}$ social $^{52}$ à qualidade de vida e ao desenvolvimento sustentável das atividades econômicas, observados os postulados (diretrizes) do Estatuto da Cidade.

Embora a expressão "qualidade de vida" seja um conceito jurídico indeterminado e, portanto, mutável e dinâmico em vista do desenvolvimento da sociedade e da alteração dos padrões de consumo ${ }^{53}$, é preciso estabelecer um conjunto de fatores (ações e instrumentos) que servirá de balizamento para um padrão mínimo de qualidade de vida ${ }^{54}$.

\footnotetext{
${ }^{47}$ Entre eles, podemos citar os órgãos colegiados de política urbana nos âmbitos nacional, estadual, municipal; debates, audiências e consultas públicas; conferências sobre assuntos de interesse urbano, nos níveis nacional, estadual e municipal; e iniciativa popular de projeto de lei e de planos, programas e projetos de desenvolvimento urbano.

${ }^{48}$ Há quem entenda que deva ser protegido o núcleo mínimo (poder de disposição) do direito de propriedade, como é o caso da garantia da justa indenização a ser fixada pelo juiz na hipótese prevista do $\S 4^{\circ}$ do artigo 1.228 do Código Civil. Sobre o assunto, confira-se CARDOSO, Fernanda Lousada. Propriedade Privada Urbana Obriga? Análise do Discurso Doutrinário e da Aplicação Jurisprudencial. Rio de Janeiro: Renovar, 2008.

${ }^{49}$ CARRERA, Francisco. Cidade Sustentável. Utopia ou Realidade? Rio de Janeiro: Lúmen Júris, 2005, p. 100.

${ }^{50}$ GARCIA, Maria. Coord. A Cidade e seu Estatuto. São Paulo: Juarez de Oliveira, 2005, p. 40: "Para que serve uma Cidade? Acontece na interseção público/privado: habitar em comum, mantendo as distinções, as individualidades".
}

${ }^{51}$ SANCHÍS, Luis Pietro. Apuntes de teoria del Derecho. 2. ed. Madrid: Editorial Trotta, 2007, p. 99: "el Derecho positivo ha incorporado gran parte de los contenidos o valores de justicia". CUNHA, Paulo Ferreira. Filosofia do Direito. Coimbra: Almedina, 2004, p. 189-192: "a Justiça, que segundo refere uma glosa, é mãe do Direito, tem dificuldades idênticas não por vicissitudes civilizacionais, mas por razões temporais. Cada tempo se concentra em alguns dos seus aspectos, dela projectando uma diversa imagem. Elenquemos rapidamente o que pode ser a Justiça, ou seja, em que categoriais se manifesta ela: como uma virtude, como um valor, como um princípio - sobretudo. (...) A Justiça passa de algum modo a encontrar-se num Direito Natural de princípios. E as grandes Declarações de Direitos e Constituições modernas serão os arautos de tal Direito Natural. O qual, de tão positivado, se arriscou a tornar-se supérfluo. Menos ambiciosos, os tempos seguintes de vez em quando invocam o princípio da Justiça. Hoje se invoca em alguns ramos mais que noutros. O valor Justiça corresponde, por seu turno, a uma fase moderna axiologizada e laicizada. Mas todas as teorias são de todos os tempos. E nos nossos dias, neste nosso tempo de confluências e encruzilhadas, a Justiça pode e talvez deva ser virtude, valor e princípio. E pode ser outras coisas. Por exemplo, à falta de Bem Comum, conceito cheio de significado, mas por vezes contado negativamente, fala-se cada vez mais em Justiça Social. As Justiças adjectivadas abundam. Temos de perseguir nas palavras os sentidos para além das circunstâncias dos tempos".

52 A noção de justiça social derivada da igualdade se infere, segundo parece-me, da seguinte passagem de RAWLS, John. O Direito dos Povos. Rio de Janeiro: Martins Fontes, 2004, p. 46: "Inicialmente, podemos supor que o resultado de elaborar o Direito dos Povos apenas para sociedades democráticas liberais será a adoção de certos princípios da igualdade entre os povos. Esses princípios, suponho, também abrirão espaço para várias formas de associação e federações cooperativas entre os povos, mas não afirmarão um Estado mundial".

${ }^{53}$ MUKAI, Toshio. Direito Urbano e Ambiental. 3. ed. Belo Horizonte: Fórum, 2006, p. 31: "Como o urbanismo, hoje, tem seus objetivos ampliados para alcançar não só as quatro funções do homem (habitação, 
Tais fatores hão de ser suficientes e necessários à garantia de um standard digno de vida ao homem e ao atendimento dos anseios das futuras gerações, que se relaciona com uma mínima implementação dos direitos sociais ${ }^{55}$ (artigos $6^{\circ}$ e 225 da CF), cujo fundamento está assentado no princípio da solidariedade (artigo $3^{\circ}$, I, da CF). Direitos sociais promovem o direito às cidades sustentáveis ${ }^{56}$. A propósito da fundamentação dos direitos sociais no princípio da solidariedade, remetemos à lição de Vicente de Paulo Barreto ${ }^{57}$ :

\begin{abstract}
"Existe, modernamente, uma outra linha de investigação e argumentação que sustenta haver uma dependência necessária e lógica entre os direitos humanos e os direitos sociais. $O$ argumento de que os direitos sociais inserem-se na categoria dos direitos humanos tem sido desenvolvido em torno da idéia de que a responsabilidade social do Estado é uma das dimensões definidoras do estado democrático de direito, idéia essa que se encontra consagrada em diferentes textos constitucionais sob a forma do princípio da solidariedade (Constituição brasileira de 1988, art. $3^{\circ}$, I). Para que essa idéia seja plenamente analisada é necessário situá-la no quadro de uma teoria normativa completa do Estado. Höffe propõe dois tipos de argumentos para legitimar a responsabilidade social do Estado e, em conseqüência, incluir os direitos sociais como direitos humanos. Os dois argumentos de Höffe fundamentam-se ambos nas raízes morais dos direitos humanos e, em função desse natureza ética, permite que se analise o problema de ângulo diferente daquele utilizado pelo economicismo". '
\end{abstract}

Corroborando com o entendimento de que os direitos sociais (de terceira geração) consagram o princípio da solidariedade, trazemos à colação os seguintes precedentes do Supremo Tribunal Federal:

“(...) Direito de terceira geração. Princípio da solidariedade. O direito à integridade
do meio ambiente. Típico direito de terceira geração. Constitui prerrogativa jurídica
de titularidade coletiva, refletindo, dentro do processo de afirmação dos direitos
humanos, a expressão significativa de um poder atribuído, não ao indivíduo
identificado em sua singularidade, mas, num sentido verdadeiramente mais
abrangente, a própria coletividade social. (...) Acentuam o princípio da igualdade,
os direitos de terceira geração, que materializam poderes de titularidade coletiva
atribuídos genericamente a todas as formações sociais, consagram o princípio da
solidariedade e constituem um momento importante no processo de

trabalho, recreação e circulação) mas também a sua melhor qualidade de vida no contexto urbano, embora seu conceito técnico não esteja ainda consolidado definitivamente, é certo que trata ele da disciplina físico-social dos espaços habitáveis, podendo ser concebido, num sentido amplo, como arte e técnica social destinadas a promover a adequação dos espaços físicos às necessidades de habitação e exercício das outras funções humanas".

${ }^{54}$ VIEIRA, Juliana de Souza Reis. Op. Cit., p. 326-327.

${ }^{55}$ Idem.

56 CAVALAZZI, Rosangela Lunardelli. O Estatuto Epistemológico do Direito Urbanístico Brasileiro: possibilidades e obstáculos na tutela do direito à cidade. In Direito da Cidade. Novas Concepções sobre as Relações Jurídicas no Espaço Social Urbano. Rio de Janeiro: Lúmen Júris, 2007, p. 57: “(...) como direito humano na categoria dos interesses difusos".

${ }^{57}$ BARRETO, Vicente de Paulo. Ética e Direitos Humanos: Aporias Preliminares. In Ricardo Lobo Torres (Org.). Legitimação dos Direitos Humanos. Rio de Janeiro: Renovar, 2002, p. 527. 
desenvolvimento, expansão e reconhecimento dos direitos humanos, caracterizados, enquanto valores fundamentais indisponíveis, pela nota de uma essencial inexauribilidade". 58

"Meio Ambiente. Direito à preservação de sua integridade (CF, Art. 225). Prerrogativa qualificada por seu caráter de metaindividualidade. Direito de Terceira Geração (ou de novíssima dimensão) que consagra o postulado da solidariedade. Necessidade de impedir que a transgressão a esse direito faça irromper, no seio da coletividade, conflitos intergeneracionais. Espaços territoriais especialmente protegidos (CF, Art. 225, $\S 1^{\circ}$, III)". ${ }^{59}$

$\mathrm{Na}$ efetivação dos direitos sociais ${ }^{60}$ é imperioso, pois, assegurar um padrão mínimo de qualidade de vida do homem nas cidades, tanto no que diz respeito às gerações presentes como também às gerações futuras, em consonância com a noção de sustentabilidade.

A idéia de sustentabilidade gravita em torno de alguns indicadores, dentre os quais destacamos: (i) crescer sem destruir; (ii) indissociabilidade da problemática ambiental e social; (iii) especificidade da Agenda Marrom $^{61}$; (iv) incentivar a inovação e a disseminação de boas práticas; (v) fortalecimento da democracia; gestão integrada e participativa; (vi) foco na ação local; (vii) mudança do enfoque das políticas de desenvolvimento e preservação; (viii) informação para tomada de decisão; e, por fim, (ix) diálogo entre as estratégias da Agenda 21 brasileira e as atuais opções de desenvolvimento ${ }^{62}$.

A implantação da sustentabilidade nas áreas urbanas e nas áreas rurais exige uma busca de padrões, ações e instrumentos práticos e de acordo com a realidade brasileira, que venham conjugar razoavelmente os diversos feixes de interesses transindividuais, públicos (ex.: políticas de governo) e particulares (ex.: empresários), pois, caso contrário, se revelará algo utópico, desprovido de consistência ${ }^{63}$.

Ademais, em razão dos vários indicadores e opções traduzidas nos possíveis valores dos recursos naturais em confronto com os diversos interesses em jogo que se

\footnotetext{
${ }^{58}$ STF, Tribunal Pleno, MS 22164/SP, Relator Ministro Celso de Mello, julgamento de 30.10.1995, DJ de 17.11.1995.

${ }^{59}$ STF, Tribunal Pleno, ADI-MC 3540/DF, Relator Ministro Celso de Mello, julgamento de 01.09.2005, DJ de 03.02.2006.

${ }^{60}$ Sobre a preservação do bem-estar social mínimo pelo Estado, as áreas e a extensão (medida) da sua intervenção, confira-se GARCIA, Eusebio Fernandez. Filosofia Política y Derecho. Madrid: Marcial Pons, 1995, p. $127-128$.

${ }^{61}$ Banco Mundial (BIRD) e o Banco Interamericano de Desenvolvimento (BID), a Agenda Marrom tem como pauta notadamente a melhoria da qualidade sanitário-ambiental das populações urbanas, indicativa, no Brasil, do princípio da universalização de saneamento ambiental nas cidades brasileiras (art. $2^{\circ}$ da Lei n. 11.445/2007). Cf. MUKAI, Toshio. Coord. Saneamento Básico: Diretrizes Gerais. Comentários à Lei 11.445 de 2007. Rio de Janeiro: Lumen Juris, 2007.

${ }^{62}$ VIEIRA, Juliana de Souza Reis. Op. Cit., p. 332-335.

${ }^{63}$ CARRERA, Francisco. Op. Cit., p. 105-106.
} 
apresentam em nossa realidade atualmente, frise-se que a orientação do desenvolvimento sustentável pode ser tratada como um problema de escolha, uma opção política ligada à estratégia de desenvolvimento a ser adotada, a qual deve pautar-se numa coerente estrutura social (artigos $3^{\circ}$, I, e $6^{\circ}$ da CF) e econômica eficiente (artigo 170 da CF), capaz de promover um adequado equilíbrio entre reprodução dos sistemas naturais e a reprodução e distribuição ${ }^{64}$ da produção social ${ }^{65}$, este relacionado ao conceito material de direito como um produto ${ }^{66}$.

O estabelecimento de conexões adequadas entre o espaço urbano (artigos $182 \mathrm{e}$ $183 \mathrm{da} \mathrm{CF}$ ) ${ }^{67}$ e o espaço rural (artigos 184 e 191 da CF) ${ }^{68} 69$ pressupõe um modelo de cidade

${ }^{64}$ RABENHORST, Eduardo Ramalho. Justiça. In BARRETO, Vicente (Coord.). Dicionário de Filosofia do Direito. Rio de Janeiro: Renovar, 2006, p. 493: "O termo justiça apresenta uma grande diversidade de significados. (...). As suas dimensões da justiça suscitam grandes discussões filosóficas. A dimensão procedimental, (...). A dimensão substancial, por sua vez, enfrenta a difícil tarefa de escolher, entre os princípios de distribuição tão antitéticos, aquele que deve ser considerado o mais adequado como também o desafio de justificar as desigualdades dele decorrentes (Perelman)". Acerca da noção (dimensão substancial) de justiça distributiva encerrando a idéia de igualdade e de proporção geométrica, confira-se lição de ARISTÓTELES, Ética a Nicômaco. São Paulo: Martin Claret, 2002, Livro V, p. 109: "Temos então que a justiça distributiva é a conjunção do primeiro termo de uma proporção com o terceiro, e do segundo com o quarto, e o justo neste sentido é o meio-termo, e o injusto é o que viola a proporção, pois o proporcional é o intermediário, e o justo é o proporcional". A respeito da idéia de Justiça Comutativa, confira-se LUMIA, Giuseppe. Elementos de Teoria e Ideologia do Direito. São Paulo: Martins Fontes, 2003, p. 137-138: “A justiça comutativa preside as relações entre os particulares, sejam elas originadas de fatos lícitos, com os contratos, sejam relações originadas de fatos ilícitos, como os delitos. Essa forma de justiça estabelece uma relação entre duas coisas, e importa uma equivalência aritmética entre a prestação e a contraprestação nas obrigações originadas por contrato, e entre o ressarcimento e o dano nas obrigações originadas por ilícito".

${ }^{65}$ DERANI, Cristiane. Direito Ambiental Econômico. 3. ed. São Paulo: Saraiva, 2008, p. 120-122.

${ }^{66}$ MOTA, Mauricio. O conceito de natureza e a reparação das externalidades ambientais negativas. In Fundamentos Teóricos do Direito Ambiental. Coord. São Paulo: Elsevier, 2008, p. 22: "O direito como um resultado de um processo de distribuição, em que cada qual tenha do todo social (dos bens que existem para distribuir) aquilo que lhe corresponda, irá postular a noção de desenvolvimento sustentável. Este implica, então, o ideal de um desenvolvimento harmônico da economia e ecologia que devem ser ajustados numa correlação de valores em que o máximo econômico reflita igualmente um máximo ecológico”.

${ }^{67}$ Estatuto da Cidade - Lei n. 10.257/2001.

${ }^{68}$ Estatuto da Terra - Lei n. 4.504/1964. Cf. LIRA, Ricardo Pereira, Op. Cit., p. 327-328 e 332: "Pelo princípio da continuidade das leis, ocorreu a recepção do Estatuto da Terra pelos textos constitucionais supervenientes, em razão da evidente compatibilidade daquela lei ordinária com a nova sistemática” (...) Como se vê é um rosário de expressões destinadas a impedir a implementação imediata de uma reforma agrária e de uma política agrícola. (...) Temos, então, que, basilarmente, as formas de utilização da terra rural no ordenamento jurídico brasileiro são aquelas previstas no Código Civil brasileiro, e na legislação extravagante, com os obstáculos, já apontados, trazidos pela Constituição Federal de 1988, representando um retrocesso nos caminhos conducentes a uma nova estrutura da propriedade fundiária no campo, ensejadora da reforma agrária".

${ }^{69}$ A propósito da função social da propriedade rural e a utilização adequada dos recursos naturais disponíveis e a preservação do meio ambiente, confira-se o julgado do STJ, 1 a Turma, REsp 821083/MG, Ministro Luiz Fux, julgamento 25.03.2008, DJ 09.04.2008: “Administrativo. Ambiental. Arts. 16 e 44 da Lei n. 4.771/65. Matrícula do imóvel. Averbação de área de reserva florestal. Necessidade. 1. A Constituição Federal consagra em seu art. 186 que a função social da propriedade rural é cumprida quando atende, seguindo critérios e graus de exigência estabelecidos em lei, a requisitos certos, entre os quais o de "utilização adequada dos recursos naturais disponíveis e preservação do meio ambiente" 2. A obrigação de os proprietários rurais instituírem áreas de reservas legais, de no mínimo $20 \%$ de cada propriedade, atende ao interesse coletivo. 3. A averbação da reserva legal configura-se, portanto, como dever do proprietário ou adquirente do imóvel rural, independentemente da existência de florestas ou outras formas de vegetação nativa na gleba. 4. Essa legislação, ao determinar a separação de parte das propriedades rurais para constituição da reserva florestal legal, resultou de uma feliz e 
apto e capaz de promover o desenvolvimento econômico sustentável e a garantir, a um só tempo, um padrão mínimo de qualidade de vida digna do homem e o atendimento às necessidades da coletividade, presente e futura (artigos $1^{\circ}$, III; $3^{\circ}$, I, II, III, IV; $6^{\circ} ; 170$ e 225 da $\mathrm{CF})$.

\section{O modelo da cidade-média como técnica urbanística para integração e sustentabilidade entre os espaços urbano e rural.}

Como visto anteriormente, o Estatuto da Cidade é um dos mais importantes pilares do Direito Urbanístico cujo novo papel, delineado pela Constituição de 1988, deve humanizar, ordenar e harmonizar os espaços ambientais habitáveis no seu conjunto cidade (urbano)-campo (rural).

O plano diretor, por sua vez, é o principal instrumento para a implantação das funções sociais da cidade que, em última instância, visa garantir o bem-estar dos seus habitantes.

Em conformidade com o $\S 2^{\circ}$ do artigo 40 do Estatuto da $\operatorname{Cidade}^{70}$, o plano diretor deve abranger tanto a zona urbana como a zona rural, haja vista que a diretriz política urbana prevista no inciso IV do artigo $2^{\circ}$ determina a integração e complementariedade entre as atividades urbanas e rurais, tendo em vista o desenvolvimento econômico do Município e do território sob sua área de influência.

$\mathrm{Na}$ ordenação do pleno desenvolvimento das funções socais da cidade e na promoção do bem estar de seus habitantes, não cabe ao Poder Público Municipal diferenciar

\footnotetext{
necessária consciência ecológica que vem tomando corpo na sociedade em razão dos efeitos dos desastres naturais ocorridos ao longo do tempo, resultado da degradação do meio ambiente efetuada sem limites pelo homem. Tais consequiências nefastas, paulatinamente, levam à conscientização de que os recursos naturais devem ser utilizados com equilíbrio e preservados em intenção da boa qualidade de vida das gerações vindouras (RMS n. 18.301/MG, DJ de 03/10/2005). 5. A averbação da reserva legal, à margem da inscrição da matrícula da propriedade, é consequiência imediata do preceito normativo e está colocada entre as medidas necessárias à proteção do meio ambiente, previstas tanto no Código Florestal como na Legislação extravagante. (REsp 927979/MG, DJ 31.05.2007) 6. Recurso Especial provido".

${ }^{70}$ Art. 40. O plano diretor, aprovado por lei municipal, é o instrumento básico da política de desenvolvimento e expansão urbana. $\S 1^{\mathrm{o}} \mathrm{O}$ plano diretor é parte integrante do processo de planejamento municipal, devendo o plano plurianual, as diretrizes orçamentárias e o orçamento anual incorporar as diretrizes e as prioridades nele contidas. $\S 2^{\circ} \mathrm{O}$ plano diretor deverá englobar o território do Município como um todo.
} 
os habitantes situados na zona rural daqueles que estão localizados na zona urbana e que guardam, entre si, estreita ligação entre as suas respectivas atividades econômicos ${ }^{71}$.

De acordo com Nelson Saule Júnior ${ }^{72}$, o sistema de planejamento municipal, que é matéria do plano diretor, deverá ser constituído por órgãos administrativos regionalizados que compreendam também a região rural. O plano diretor deverá considerar

\begin{abstract}
"a dimensão do crescimento urbano demonstra a necessidade de modificar as relações sociais e econômicas para a promoção do desenvolvimento econômico em consonância com os ditames da justiça social. Essa modificação passa pela realização da reforma urbana, articulada com a reforma agrária, em vista da relação estreita entre a questão rural, urbana e ambiental. Desse modo, para o Município promover a política de desenvolvimento urbano, deve conter um plano diretor com normas voltadas a abranger a totalidade do seu território, compreendendo a área urbana e rural. Padece de vício constitucional o plano diretor que se restringir apenas à zona urbana e de expansão urbana"73.
\end{abstract}

Entre as técnicas urbanísticas de grande alcance adotadas no início do século XX que combinam a ligação cidade-campo, destacam-se aquelas denominadas de cidadejardim, cidade-linear e novas-cidades.

A primeira foi concebida pelo inglês Ebenezer Howard por meio da qual pretendeu

\begin{abstract}
"harmonizar o ambiente urbano com o rústico, através da vivenda unifamiliar rodeada de jardim, com a finalidade de superar o contraste entre a vida urbana (caracterizada pela existência de oferta de trabalho, facilidade de trocas e de tecnologia avançada, mas igualmente pela presença de um alto nível das rendas, falta de condições higiênicas adequadas, degradação de muitos bairros residenciais e pela poluição do ar) e a vida do campo (na qual os recursos ambientais não são correctamente utilizados, devido à deficiência ou à carência total de equipamentos, à pobreza e ao baixo nível dos salários). Segundo o autor citado, para ultrapassar esta situação de contraste é necessário encontrar uma terceira via, dotada de uma vis atractiva superior à daqueles tipos de vida. Aquela deveria congregar os aspectos positivos da cidade e do campo e eliminar os factores negativos de uma de outros. Na perspectiva de Howard, essa terceira via encontra-se na edificação de aglomerados urbanos planificados de acordo com o modelo de cidade-jardim: novos núcleos urbanos independentes e afastados das grandes cidades, com casas próprias rodeadas de grandes jardins ${ }^{\text {,74 }}$.
\end{abstract}

A cidade-linear foi concebida pelo espanhol Sorya y Mata e de acordo com esta técnica urbanística,

\footnotetext{
${ }^{71}$ JUNIOR, Nelson Saule. Estatuto da Cidade e o Plano Diretor - Possibilidade de uma nova ordem legal urbana justa e democrática. In OSÓRIO, Letícia Marques (Org.). Estatuto da Cidade e Reforma Urbana. Novas Perspectivas para as Cidades Brasileiras. Porto Alegre: Sergio Antonio Fabris Editor, 2002, p. 87.

72 Op. Cit., p. 87.

${ }^{73}$ Idem., p. 88.

${ }^{74}$ CORREIA, Fernando Alves. O Plano Urbanístico e o Princípio da Igualdade. Coimbra: Almedina, 2001, p. 37-38.
} 
"a cidade mantém-se em contacto e este com aquela. Graças à distribuição dos equipamentos que decorre deste modelo, o campo pode receber em larga medida os efeitos e os benefícios da cidade. Na íntima relação cidade-campo subjacente a esta técnica, pode descortinar-se uma influência da concepção da cidade-jardim... As vantagens da organização interna da cidade inerentes a este modelo eram evidentes, já que a cidade linear, embora tivesse nascido de acordo com uma morfologia estruturalmente compatível com o meio mais revolucionário que a tecnologia da época tinha concebido - a via férrea - permitia a disposição em grandes franjas longitudinais de todas as canalizações da cidade moderna"75.

A técnica das novas cidades (new tows) enquadra-se na perspectiva global do regionalismo, a exemplo das cidades administrativas, cidades coloniais, cidades religiosas, cidades industriais criadas ex novo.

Esse modelo busca uma política de descentralização industrial e de equilíbrio regional. Vale registrar aqui as recomendações da Comissão Reith incumbida de estudar o modelo para a sua aplicação na Grande Londres:

“1) As novas cidades deviam ser edificadas a uma distância não inferior a 40 quilômetros na região de Londres e a 20 quilômetros nas outras regiões, a fim de possibilitar a constituição de núcleos de vida econômica, social e cultural realmente independentes, afastando-se, assim, a fórmula altamente negativa das cidades-satélites ou das cidades-dormitório, com o cortejo das deslocações quotidianas massivas entre as residências e os locais de trabalho. 2) As distâncias destas novas cidades em relação aos centros metropolitanos não podem ser demasiado elevadas, devido à necessidade de atrair certas indústrias e serviços que exigem a manutenção de contactos entre os dois aglomerados. 3) A dimensão das novas cidades devia mover-se entre 20.000 e 60.000 habitantes, de modo a facilitar as deslocações a pé ou em bicicleta entre a residência e os locais de trabalho, que deveriam situar-se nas próprias cidades, assim como todos os serviços e meios culturais necessários para garantir a sua autonomia. 4) Uma cintura verde e um zoneamento rigoroso teriam como função impedir o crescimento ilimitado destes núcleos, cuja densidade populacional deveria manterse baixa". 76

A Constituição Federal de $1988^{77}$ conferiu autonomia aos Municípios quanto aos aspectos político, administrativo e financeiro ${ }^{78}$, o que representa a sua capacidade de auto-

${ }^{75}$ Idem., p. 38-39.

${ }^{76}$ Idem., p. 44-45: "Estas sugestões tiveram realização prática, embora com algumas adaptações. No círculo de Londres foram criadas oito novas cidades, localizadas a uma distância que varia entre 32 e 49 quilômetros do centro, sendo as mais famosas as de Stevenage e Harlow. Outras sugeriam na escócia, País de Gales e em outras áreas metropolitanas, num total de vinte e oito. A técnica das novas cidades irradiou para outros países, como a Suécia, Dinamarca, Finlândia, Holanda, França, E.U.A., bem como para alguns países do leste europeu”.

${ }^{77}$ Art. $1^{\circ}$ A República Federativa do Brasil, formada pela união indissolúvel dos Estados e Municípios e do Distrito Federal, constitui-se em Estado Democrático de Direito (...). Art. 18. A organização políticoadministrativa da República Federativa do Brasil compreende a União, os Estados, o Distrito Federal e os Municípios, todos autônomos, nos termos desta Constituição.

${ }^{78}$ Art. 29. O Município reger-se-á por lei orgânica, votada em dois turnos, com o interstício mínimo de dez dias, e aprovada por dois terços dos membros da Câmara Municipal, que a promulgará, atendidos os princípios 
organização, autogoverno, autolegislação (destaca-se aqui a elaboração da suas próprias Leis Orgânicas) e auto-administração, de maneira a determinar a sua própria vida, observados os limites constitucionalmente estabelecidos ${ }^{79}$.

Em vista do processo de descentralização do poder público inaugurado pela Carta Constitucional com o fortalecimento dos governos municipais, cumpre a estes adotar novos arranjos territoriais visando à maior eficiência na gestão especial, que, segundo Ângela Moulin S. Penalva Santos ${ }^{80}$, incluem: a) consórcios municipais, b) regiões metropolitanas, e c) regiões integradas de desenvolvimento econômico.

A realidade brasileira é composta por regiões mais desenvolvidas (Sudeste e Sul) e regiões menos desenvolvidas. Neste cenário, tende a cidade-média a desempenhar melhor o seu papel de maior protagonismo na gestão do espaço territorial, cuja articulação se desenvolve por meio do espaço eletrônico, resultante das novas tecnologias e responsável pela compressão tempo-espaço. Mantém-se no topo dessa nova hierarquia a cidade global que, por sua vez, consolida o seu papel de comandante do território em escala global ${ }^{81}$.

A sustentação de um novo recorte territorial, a chamada cidade-média, que vem se tornando os elos mais densos entre a rede rural e a rede urbana, representa um importante instrumento de organização do território (interno) na atual ordem econômica internacional, com o fortalecimento dos governos municipais ${ }^{82}$. Contribui-se, assim, para a implantação de um novo modo de estruturação da dinâmica da atividade econômica,

estabelecidos nesta Constituição, na Constituição do respectivo Estado e os seguintes preceitos: (...). Art. 29-A. O total da despesa do Poder Legislativo Municipal, incluídos os subsídios dos Vereadores e excluídos os gastos com inativos, não poderá ultrapassar os seguintes percentuais, relativos ao somatório da receita tributária e das transferências previstas no $\S 5^{\mathrm{o}}$ do art. 153 e nos arts. 158 e 159 , efetivamente realizado no exercício anterior: (...). Art. 30. Compete aos Municípios: I - legislar sobre assuntos de interesse local; II - suplementar a legislação federal e a estadual no que couber; III - instituir e arrecadar os tributos de sua competência, bem como aplicar suas rendas, sem prejuízo da obrigatoriedade de prestar contas e publicar balancetes nos prazos fixados em lei; IV - criar, organizar e suprimir distritos, observada a legislação estadual; V - organizar e prestar, diretamente ou sob regime de concessão ou permissão, os serviços públicos de interesse local, incluído o de transporte coletivo, que tem caráter essencial; VI - manter, com a cooperação técnica e financeira da União e do Estado, programas de educação infantil e de ensino fundamental; VII - prestar, com a cooperação técnica e financeira da União e do Estado, serviços de atendimento à saúde da população; VIII - promover, no que couber, adequado ordenamento territorial, mediante planejamento e controle do uso, do parcelamento e da ocupação do solo urbano; IX promover a proteção do patrimônio histórico-cultural local, observada a legislação e a ação fiscalizadora federal e estadual.

${ }^{79}$ FERRARI, Regina Maria Macedo Nery. Direito Municipal. 2. ed. São Paulo: R.T., 2005, p. 85-88.

${ }^{80}$ SANTOS, Ângela Moulin S. Penalva. Município, Descentralização e Território. Rio de Janeiro: Forense, 2008, p. 161-162: “A distribuição espacial desses arranjos territoriais sugere uma nova forma de estruturação do território pela qual nas regiões mais desenvolvidas (Sudeste e Sul) a iniciativa da associação e dos próprios municípios, que usufruem o maior empoderamento que a descentralização das políticas públicas lhe proporcionou; nas regiões menos desenvolvidas, os municípios não conseguem ser atores da mesma relevância e dependem muito mais das esferas estadual e federal do governo".

${ }^{81}$ Idem., p. 162-163.

${ }^{82}$ Idem, p. 164-180. 
permitindo a articulação entre as grandes cidades (globais) e as demais cidades (médias e pequenas), aumentando a importância destas como agentes do processo de descentralização das políticas públicas. No processo de organização e ordenação espaço urbano-rural é preciso pensar em um todo articulado entre as cidades, sendo, pois, relevante o papel desempenhado pela cidade-média.

O êxito desse modelo territorial da cidade-média dependerá de uma atividade econômica sustentável, geradora de alimentos, de insumos (energia), de serviços de saúde, de saneamento, de lazer, de educação, etc. que contribuem para um padrão mínimo de qualidade de vida digna da coletividade, presente e futura ${ }^{83}$. Essa atividade econômica sustentável deverá favorecer e inspirar a criação de produtos para o consumo quantitativo e qualitativo, bem como contar com a participação de diversos atores sociais (empresas, mídias, Ong's, governos, consumidores), contribuindo para transformação de modo sustentável a natureza em "bem de consumo" 84 .

Ao cabo do exposto, conclui-se que, assegurada uma gestão democrática, por meio da participação da população e de associações representativas dos vários segmentos da comunidade, aliado à cooperação entre os governos, a iniciativa privada e os demais setores da sociedade, o recorte territorial do modelo da cidade-média é uma opção de escolha a ser considerada pelo Poder Público Municipal no plano diretor da cidade, que se revela adequado a promover a integração e sustentabilidade entre os espaços urbano e o espaço rural, com o objetivo de melhor ordená-la. A cidade-média tende a garantir de modo mais eficaz o direito a uma cidade sustentável, a qual deve ser entendida como o direito à terra urbana, à moradia, ao saneamento ambiental, à infra-estrutura urbana, ao transporte e aos serviços públicos, ao trabalho e ao lazer, para as gerações presentes e futuras, em proveito do valor supremo da dignidade da pessoa humana.

\section{Bibliografia:}

\footnotetext{
${ }^{83} \mathrm{O}$ solo, em especial o rural, tem incomensurável valor, tanto para os particulares, como para o povo em seu conjunto. Confira-se, LIRA, Ricardo Pereira, Op. Cit., 312: "Nele se radicam a fonte de alimentação das gentes, as riquezas criadoras dos instrumentos elementares para a satisfação das incontáveis necessidades vitais, e todo o sistema habitacional dos seres humanos. Dele se extraem as substâncias curativas e de fortalecimento, as possibilidades inesgotáveis de recreio e lazer, e, sobretudo, nele se exerce basicamente a liberdade essencial do homem de ir e vir. O solo é toda hipótese e possibilidade de vida".

${ }^{84}$ TAVARES, Fred, IRVING, Marta de Azevedo, MOTTA, Luiz Eduardo. A questão ambiental como inspiração para o consumo verde no Brasil. In MOTA, Mauricio (Coord.). Fundamentos Teóricos do Direito Ambiental. São Paulo: Elsevier, 2008, p. 183-206.
} 
ANTUNES, Luis Filipe Colaço. Direito Urbanístico. Um outro paradigma: A Planificação Modesto-Situacional. Coimbra: Almedina, 2002.

ARISTÓTELES, Ética a Nicômaco. São Paulo: Martin Claret, 2002.

BOBBIO, Noberto. Teoria do Ordenamento Jurídico. trad. Maria Celeste Cordeiro Leite dos Santos. 10. ed., Brasília: UnB, 1999.

BONIZZATO, Luigi, Propriedade Urbana Privada \& Direitos Sociais. Curitiba: Juruá, 2007.

BARROSO, Luís Roberto. Temas de Direito Constitucional. 2. ed. Rio de Janeiro: Renovar, 2002.

BARRETO, Vicente de Paulo. Ética e Direitos Humanos: Aporias Preliminares. In Legitimação dos Direitos Humanos. Org. Ricardo Lobo Torres. Rio de Janeiro: Renovar, 2002.

Renovar, 2006.

Coord. In Dicionário de Filosofia do Direito. Rio de Janeiro:

CAMMAROSANO, Márcio. Fundamentos constitucionais do Estado da Cidade. Estatuto da Cidade (Comentários à Lei Federal 10.257/2001). 2. ed. Coordenadores DALLARI, Adilson Abreu, FERRAZ, Sérgio. São Paulo: Malheiros, 2006.

CARDOSO, Fernanda Lousada. Propriedade Privada Urbana Obriga? Análise do Discurso Doutrinário e da Aplicação Jurisprudencial. Rio de Janeiro: Renovar, 2008.

CARRERA, Francisco. Cidade Sustentável. Utopia ou Realidade? Rio de Janeiro: Lúmen Júris, 2005.

CAVALAZZI, Rosangela Lunardelli. O Estatuto Epistemológico do Direito Urbanístico Brasileiro: possibilidades e obstáculos na tutela do direito à cidade. In Direito da Cidade. Novas Concepções sobre as Relações Jurídicas no Espaço Social Urbano. Rio de Janeiro: Lúmen Júris, 2007.

CORREIA, Fernando Alves. O Plano Urbanístico e o Princípio da Igualdade. Coimbra: Almedina, 2001.

CUNHA, Paulo Ferreira. Filosofia do Direito. Coimbra: Almedina, 2004.

ENTERRÍA, Eduardo García de. La Constitución como Norma y el Tribunal Constitucional. Madrid: Civitas, 1994.

FERRARI, Regina Maria Macedo Nery. Direito Municipal. 2. ed. São Paulo: R.T., 2005.

FILHO, José dos Santos Carvalho. Comentários ao Estatuto da Cidade. Rio de Janeiro: Lúmen Júris, 2005.

FIORILlO, Celso Antonio Pacheco. Estatuto da Cidade Comentado. 3. ed. São Paulo: R.T., 2008 
GARCIA, Maria. Coord. A Cidade e seu Estatuto. São Paulo: Juarez de Oliveira, 2005.

GARCIA, Eusebio Fernandez. Filosofia Política y Derecho. Madrid: Marcial Pons, 1995.

GIORGIANNI, Michelli. Direito Privado e as suas atuais fronteiras. In Revista dos Tribunais, São Paulo, vol. 747, jan. 1998.

JUNIOR, Nelson Saule. Estatuto da Cidade e o Plano Diretor - Possibilidade de uma nova ordem legal urbana justa e democrática. In. Estatuto da Cidade e Reforma Urbana. Novas Perspectivas para as Cidades Brasileiras. Letícia Marques Osório (Org.). Porto Alegre: Sergio Antonio Fabris Editor, 2002.

LIRA, Ricardo Pereira. Elementos de Direito Urbanístico. Rio de Janeiro: Renovar, 1997.

Direito Urbanístico, Estatuto da Cidade e Regularização Fundiária. In Direito da Cidade. Novas Concepções sobre as Relações Jurídicas no Espaço Social Urbano. Rio de Janeiro: Lúmen Júris, 2007.

LUMIA, Giuseppe. Elementos de Teoria e Ideologia do Direito. São Paulo: Martins Fontes, 2003

MAIA, Antônio Cavalcanti. As Transformações dos Sistemas Jurídicos Contemporâneos: Apontamentos acerca do neoconstitucionalismo. In Revista de Direito do Estado, $\mathrm{n}^{\mathrm{o}} 5$, janeiro/março, 2007.

MACHADO, Paulo Affonso Leme. Direito Ambiental Brasileiro. 16 ${ }^{\mathrm{a}}$ ed. São Paulo: Malheiros, 2008.

MEDAUAR, Odete. Estatuto da Cidade. Comentários. 2. ed. São Paulo: R.T., 2004.

MEIRELLES, Hely Lopes. Direito Municipal Brasileiro. 11. ed. São Paulo: Malheiros, 2000.

MORAES, Maria Celina Bodin de. O Princípio da Dignidade Humana. In Princípios do Direito Civil Contemporâneo. Rio de Janeiro: Renovar, 2006.

MOTA, Maurício. Questões de Direito Civil Contemporâneo. Rio de Janeiro: Elsevier, 2008.

$O$ conceito de natureza e a reparação das externalidades ambientais negativas. In Fundamentos Teóricos do Direito Ambiental. Coord. São Paulo: Elsevier, 2008 .

MOREIRA, Bruno, MARANGONI, Marina, CASTILHO, Rafael. As áreas de Proteção Ambiental e os Impostos sobre a Propriedade. In Direito Tributário Ambiental. Coord. ORLANDO, Breno Ladeira Kingma, GUDIÑO, Daniel Mariz, TROUW, Ernesto Johannes, GONÇALVES, Fábio Fraga, MUNIZ, Igor, MURAYAMA, Janssen Hiroshi. Rio de Janeiro: Lúmen Júris, 2008.

MUKAI, Toshio. Direito Urbano e Ambiental. 3. ed. Belo Horizonte: Fórum, 2006.

. Coord. Saneamento Básico: Diretrizes Gerais. Comentários à Lei 11.445 de 2007. Rio de Janeiro: Lumen Juris, 2007 
NEGREIROS, Teresa. Dicotomia Público-Privado frente ao Problema da Colisão de Princípios. In Teoria dos Direitos Fundamentais. Org. Ricardo Lobo Torres. Rio de Janeiro: Renovar, 1999.

NETO, Diogo de Figueiredo Moreira. Introdução ao Direito Ecológico e ao Direito Urbanístico. $2^{\text {a }}$ ed. Rio de Janeiro: Forense, 1977.

OLIVEIRA, Regis Fernandes de. Comentários ao Estatuto da Cidade. $2^{\mathrm{a}}$ ed. São Paulo: R.T., 2005.

PERLINGIERI, Pietro. Perfis de Direito Civil - Introdução ao Direito Civil Constitucional. Rio de Janeiro: Renovar, 1999.

RAWLS, John. O Direito dos Povos. Rio de Janeiro: Martins Fontes, 2004.

RABENHORST, Eduardo Ramalho. Justiça. In Dicionário de Filosofia do Direito. BARRETO, Vicente. Coord. Rio de Janeiro: Renovar, 2006.

SANCHÍS, Luis Pietro. Apuntes de teoria del Derecho. 2. ed. Madrid: Editorial Trotta, 2007.

SANTOS, Ângela Moulin S. Penalva. Município, Descentralização e Território. Rio de Janeiro: Forense, 2008.

SÉGUIN, Elida. Estatuto da Cidade. 2. ed. Rio de Janeiro: Forense, 2005.

. O Direito Ambiental. 3. ed. Rio de Janeiro: Forense, 2006.

SILVA, José Afonso da. Direito Urbanístico Brasileiro. 5. ed. São Paulo: Malheiros, 2008.

Direito Ambiental Constitucional. 6. ed. São Paulo: Malheiros, 2008.

SUNDFELD, Carlos Ari. O Estatuto da Cidade e as suas diretrizes gerais. In Estatuto da Cidade (Comentários à Lei Federal 10.257/2001). 2. ed. Coordenadores DALLARI, Adilson Abreu, FERRAZ, Sérgio. São Paulo: Malheiros, 2006.

TEPEDINO, Gustavo. Premissas Metodológicas para a Constitucionalização do Direito Civil. In Temas de Direito Civil. Rio de Janeiro: Renovar, 1999.

TORRES, Marcos Alcino de Azevedo. Instrumentos Urbanísticos e a Propriedade Urbana Imóvel. In Problemas de Direito Civil-Constitucional. TEPEDINO, Gustavo. Coord. Rio de Janeiro: Renovar, 2000.

VICHI, Bruno de Souza, Política Urbana. Sentido jurídico, competências e responsabilidades. Belo Horizonte: Fórum, 2007.

VIEIRA, Juliana de Souza Reis. Cidades Sustentáveis. In Fundamentos Teóricos do Direito Ambiental. Coord. MOTA, Mauricio. São Paulo: Elsevier, 2008. 